\title{
VARIATION IN WOOD PHYSICAL PROPERTIES OF EUCALYPTUS PELLITA GROWING IN SEEDLING SEED ORCHARD IN PLEIHARI, SOUTH KALIMANTAN
}

\author{
Siti Susilawati ${ }^{1}$ and Sri Noegroho Marsoem ${ }^{2}$
}

\begin{abstract}
This study shows an effort to obtain the best performance of Eucalyptus pellita trees, which was conducted by examining the physical properties of wood of 116 months age Eucalyptuspellita trees. The trees of various families used in this study were all grown in Seedling Seed Orchard (SSO), Pleihari. A total of 10 families with 3 individual trees for each family as replication were randomly selected for the whole SSO. Selected sample trees were felled, cut and divided into three different parts (bottom, middle and top) of the stem. Each stem part was then cut into wood samples running from pith to bark portion for the examination of its physical properties according to British Standard BS 373-1957. The collected data on those properties were analyzed by using a completely randomized design (CRD). The results showed that there were significant differences in wood density and fiber length among different height, and among wood sections from pith to bark in individual trees as well as among families. Wood density showed high family heritability $(0.708)$ and genetic correlation between wood density and fiber length were significantly different $(\mathrm{r}=0.543)$.
\end{abstract}

Keywords : Eucalyptus pellita, physical properties, density, fiber, shrinkage

\section{INTRODUCTION}

The Center for Forest Plantation Research and Development (Yogyakarta) in collaboration with Japan International Cooperation Agency (JICA) established a Seedling Seed Orchard (SSO) of Eucalyptus pellita in Pleihari, South Kalimantan in January - March 1994. Before assigning the SSO, E. pellita plantation was established as a progeny test trial plot. It consisted of 155 families from 6 provenances i.e. South of Kiriwo, North of Kiriwo, Serisssa Village and Keru Tonata in Papua New Guinea (PNG); Tozers Gap in Queensland (Australia); and Bupul Muting Merauke in West Papua (Indonesia).

Up to 5 years old, performance evaluation on SSO was mostly based on growth parameters such as height and diameter (Leksono and Kurinobu, 2002; Leksono and Setyaji, 2004). Later on, Susilawati and Fujisawa (2002) had evaluated the performance of juvenile wood of 66 months old E. pellita growing in Pleihari's SSO, South Kalimantan and found that its wood density and fiber length were greater than high improvement criteria for wood quality.

\footnotetext{
${ }^{1}$ Forest Plantation Research and Development Center, Yogyakarta

${ }^{2}$ Faculty of Forestry, Gadjah Mada University, Yogyakarta
} 
E. pellita did not only possess a high growth rate in height and diameter (Harwood et al., 1997) but also have high family heritability up to 5 years old (Leksono and Setyaji, 2004). Therefore, it is one of the potential and promising species for Timber Estate Program in Indonesia.

This paper presents a study on variation in physical properties of E. pellita wood of 116 months old inside stem and between families in Pleihari's SSO, South Kalimantan. Physical properties observed were limited to the parameters that could affect the end-use of E. pellita for pulp and paper, limited construction and furniture. They include wood density, fiber length, and shrinkage in radial, tangential and longitudinal directions.

\section{METHODOLOGY}

\section{A. Sample Collection and Measurement}

The sampling criterion used in selecting the sample trees was diameter class (small, medium, and large). A total of 10 families, each with 3 individual trees as replication were selected from the whole SSO.

Selected sample trees were felled, cut, and divided into three different parts (bottom, middle and top) of the stem. Each stem part was then cut into wood samples running from pith to bark portions for the measurement of their physical properties according to British Standard BS 373-1957 (Anonim, 1957). Information about selected sample trees is described in Table 1.

\section{B. Data Analysis}

The collected and examined data were referring to variation in wood physical properties inside the stem as well as among the families of E. pellita trees. The data variation were analyzed using a completely randomized design (CRD) with factorial pattern. The factors were family (A); vertical tree part (B) that consists of top, middle, and bottom portion; and wood section $(\mathrm{C})$ that ran horizontally from pith to bark. Should any of the individual factors $(A, B$, or $C$ ) and their interaction $(A B, A C, B C$, or $A B C)$ reveal significant effects, the analysis was continued with the Duncan Multiple Ranges Test (DMRT) for the differences among the means of wood physical properties. 
Table 1. Information of sample trees for physical properties measurement of E. pellita in Pleihari's SSO (Seedling Seed Orchard), South Kalimantan, Indonesia.

\begin{tabular}{|c|c|c|c|c|c|c|c|c|}
\hline $\begin{array}{c}\text { Sample } \\
\text { no. }\end{array}$ & Row & Col umn & $\begin{array}{l}\text { Family } \\
\text { number }\end{array}$ & $\begin{array}{c}\text { FTIP* } \\
\text { no }\end{array}$ & $\begin{array}{l}\text { Seed } \\
\text { Lot no }\end{array}$ & Tree no & Seed sources / origin & $\begin{array}{c}\text { Planting } \\
\text { year }\end{array}$ \\
\hline 1 & 25 & 14 & 2 & 366 & 18197 & CG 1893 & S OF KIRIWO WP & $93 / 94$ \\
\hline 2 & 38 & 8 & 2 & 366 & 18197 & CG 1893 & S OF KIRIWO WP & $93 / 94$ \\
\hline 3 & 49 & 15 & 2 & 366 & 18197 & CG 1893 & S OF KIRIWO WP & $93 / 94$ \\
\hline 4 & 7 & 24 & 3 & 367 & 18197 & CG 1894 & S OF KIRIWO WP & $93 / 94$ \\
\hline 5 & 10 & 11 & 3 & 367 & 18197 & CG 1894 & S OF KIRIWO WP & $93 / 94$ \\
\hline 6 & 50 & 27 & 3 & 367 & 18197 & CG 1894 & S OF KIRIWO WP & $93 / 94$ \\
\hline 7 & 6 & 22 & 8 & 372 & 18197 & CG 1900 & S OF KIRIWO WP & $93 / 94$ \\
\hline 8 & 15 & 27 & 8 & 372 & 18197 & CG 1900 & S OF KIRIWO WP & $93 / 94$ \\
\hline 9 & 34 & 29 & 8 & 372 & 18197 & CG 1900 & S OF KIRIWO WP & $93 / 94$ \\
\hline 10 & 14 & 17 & 14 & 378 & 17854 & MM 001298 & BUPUL-MUTING, IRIAN JAYA & $93 / 94$ \\
\hline 11 & 22 & 23 & 14 & 378 & 17854 & MM 001298 & BUPUL-MUTING, IRIAN JAYA & $93 / 94$ \\
\hline 12 & 33 & 19 & 14 & 378 & 17854 & MM 001298 & BUPUL-MUTING, IRIAN JAYA & $93 / 94$ \\
\hline 13 & 11 & 24 & 23 & 387 & 17854 & MM 001309 & BUPUL-MUTING, IRIAN JAYA & $93 / 94$ \\
\hline 14 & 28 & 20 & 23 & 387 & 17854 & MM 001309 & BUPUL-MUTING, IRIAN JAYA & $93 / 94$ \\
\hline 15 & 49 & 24 & 23 & 387 & 17854 & MM 001309 & BUPUL-MUTING, IRIAN JAYA & $93 / 94$ \\
\hline 16 & 6 & 30 & 24 & 388 & 17854 & MM 001310 & BUPUL-MUTING, IRIAN JAYA & $93 / 94$ \\
\hline 17 & 37 & 14 & 24 & 388 & 17854 & MM 001310 & BUPUL-MUTING, IRIAN JAYA & $93 / 94$ \\
\hline 18 & 47 & 20 & 24 & 388 & 17854 & MM 001310 & BUPUL-MUTING, IRIAN JAYA & $93 / 94$ \\
\hline 19 & 6 & 16 & 48 & 412 & 18197 & BVG 2146 & S OF KIRIWO WP & $93 / 94$ \\
\hline 20 & 12 & 23 & 48 & 412 & 18197 & BVG 2146 & S OF KIRIWO WP & $93 / 94$ \\
\hline 21 & 23 & 26 & 48 & 412 & 18197 & BVG 2146 & S OF KIRIWO WP & $93 / 94$ \\
\hline 22 & 16 & 17 & 51 & 415 & 18197 & CG 1867 & S OF KIRIWO WP & $93 / 94$ \\
\hline 23 & 32 & 23 & 51 & 415 & 18197 & CG 1867 & S OF KIRIWO WP & $93 / 94$ \\
\hline 24 & 43 & 19 & 51 & 415 & 18197 & CG 1867 & S OF KIRIWO WP & $93 / 94$ \\
\hline 25 & 21 & 26 & 60 & 424 & 18197 & CG 1876 & S OF KIRIWO WP & $93 / 94$ \\
\hline 26 & 41 & 17 & 60 & 424 & 18197 & CG 1876 & S OF KIRIWO WP & $93 / 94$ \\
\hline 27 & 46 & 30 & 60 & 424 & 18197 & CG 1876 & S OF KIRIWO WP & $93 / 94$ \\
\hline 28 & 8 & 28 & 62 & 426 & 18197 & CG 1878 & S OF KIRIWO WP & $93 / 94$ \\
\hline 29 & 14 & 11 & 62 & 426 & 18197 & CG 1878 & S OF KIRIWO WP & $93 / 94$ \\
\hline 30 & 34 & 16 & 62 & 426 & 18197 & CG 1878 & S OF KIRIWO WP & $93 / 94$ \\
\hline
\end{tabular}

Remarks: *FTIP = Forest Tree Improvement Project

Heritability was calculated from component of variance of each of the tested traits in accordance with Zobel and Talbert (1984). Heritability estimates were derived from the relative performance of the progenies within and between parent trees. The formula used to calculate family heritability was simplified from Wright (1976). The formula used for family heritability is as follow:

$$
\mathrm{h}_{\mathrm{F}}{ }^{2}=\quad \begin{gathered}
\sigma_{\mathrm{F}}^{2} \\
-\left(\mathrm{MS}_{\mathrm{F}} / \operatorname{coef} \sigma_{\mathrm{F}}^{2}\right)
\end{gathered}
$$

where $\mathrm{h}_{\mathrm{F}}{ }^{2}=$ family heritability; $\mathrm{MS}_{\mathrm{F}}=$ mean square of variance component of family; coef $\sigma_{\mathrm{F}}^{2}=$ coefficient of variance component of family. 


\section{RESULTS AND DISCUSSION}

The results of measurement on wood density, fiber length, and shrinkage of E pellita are shown in Figures 1 and 2 for variation inside the stem, and Figure 3 for variation between families. The statistical analysis is summarized in Table 2 and the estimated mean value of the genetic parameter and family heritability are described in Table 3. The result of DMRT analysis is attached in Appendix 1.

\section{A. Variation in Wood Physical Properties Inside E. pellita Stems}

Wood density and fiber length of E. pellita in axial and radial direction are shown in Appendix 2 and 3, while, tangential, radial and longitudinal shrinkage are shown in Appendix 4.

Wood density and fiber length inside stem, as it is described in Table 2, vary significantly both in axial and radial positions. In term of shrinkage, the significant variation is limited only for radial and tangential shrinkages in radial position (running horizontally from pith to bark). On the contrary, longitudinal shrinkages were not significantly different either in axial or radial positions.

Table 2. Analysis of variance on physical properties of E. pellita in Pleihari's SSO Pleihari, South Kalimantan

\begin{tabular}{|c|c|c|c|c|c|}
\hline \multirow{4}{*}{ Source of variation } & \multicolumn{5}{|c|}{ Examined physical properties parameters } \\
\hline & \multirow{2}{*}{$\begin{array}{l}\text { Wood } \\
\text { density }\end{array}$} & \multirow{2}{*}{$\begin{array}{l}\text { Fiber } \\
\text { length }\end{array}$} & \multicolumn{3}{|c|}{ Shrinkages } \\
\hline & & & Tangential & Radial & Longitudinal \\
\hline & \multicolumn{5}{|c|}{ Probability of F -test $(\operatorname{Pr}>)$} \\
\hline Family, A & $0.0001 * *$ & $0.0001 * *$ & 0.2193 & $0.0050 * *$ & $0.0347^{*}$ \\
\hline $\begin{array}{l}\text { Axial tree part (from bottom, middle } \\
\text { to top portion), B }\end{array}$ & $0.0001 * *$ & $0.0001 * *$ & 0.2336 & 0.1808 & 0.5868 \\
\hline $\begin{array}{l}\text { Horizontal wood section (pith to } \\
\text { bark), C }\end{array}$ & $0.0001 * *$ & $0.0001 * *$ & $0.0001 * *$ & $0.0097 * *$ & 0.3305 \\
\hline \multicolumn{6}{|l|}{ Interactions : } \\
\hline $\mathrm{A} \times \mathrm{B}$ & 0.6739 & 0.1389 & 0.1909 & $0.0002 * *$ & $0.0001 * *$ \\
\hline$A \times C$ & $0.0346^{*}$ & $0.0001 * *$ & 0.153 & 0.496 & 0.1132 \\
\hline $\mathrm{B} \times \mathrm{C}$ & 0.8095 & 0.5116 & 0.9776 & 0.0975 & 0.3015 \\
\hline $\mathrm{A} \times \mathrm{B} \times \mathrm{C}$ & 1 & 0.6695 & 0.9738 & 0.7272 & 0.9559 \\
\hline
\end{tabular}

Remarks: *) significantly difference (95\%) **) highly significant difference $(99 \%)$

Based on Duncan's Multiple Ranges Test (DMRT) as described in Appendix 1, it is found that in axial position, wood density gives opposite response as compared to fiber length. In radial position, however, all the tested parameters showed similar trends in that they tended to increase from pith to bark. Further, Figures 1, 2 and 3 describe clearly the variation in wood density, fiber length and shrinkages inside the stem when viewed either axially (bottom, middle and top) or radially (from pith to bark). 

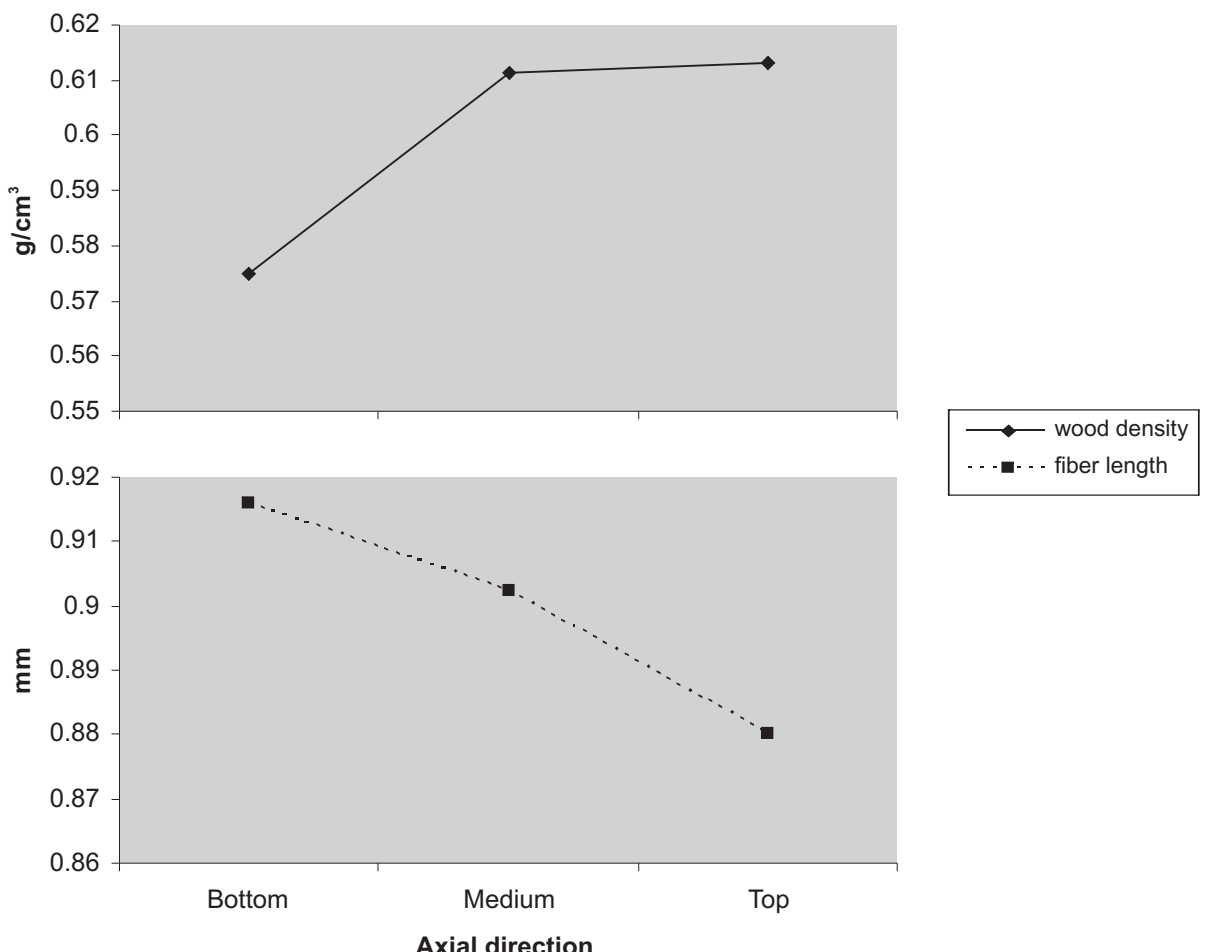

Figure 1. Variation in wood density (above) and fiber length (bottom) of E. pellita in axial direction of Pleihari's SSO, South Kalimantan

\section{B. Family Variation and Heritability of Physical Properties Parameter}

Referring to Table 2, it turned out that there were highly significant differences among families in terms of wood density, fiber length, and both radial and longitudinal shrinkages. However, the differences in tangential shrinkage among families were not significant.

Based on the DMRT for family-accounted variation as described in Appendix 1 and the overall mean of genetic parameter test in Table 3, it showed that family-accounted variation revealed different trend or specific patterns in each of the overall tested parameter (wood density, fiber length, and shrinkages). Wood density, for example, had an average mean of $0.598 \mathrm{~g} / \mathrm{cm}^{3}$, which ranged from 0.556 (family no 51 ) to $0.652 \mathrm{~g} / \mathrm{cm}^{3}$ (family no 60 ). On the other hand, the best performance of fiber length was attributed by family no $48(0.939 \mathrm{~mm})$ followed in decreasing order by family no $24(0.918 \mathrm{~mm})$, and the shortest was family no 2 $(0.874 \mathrm{~mm})$. The overall mean of fiber length was $0.904 \mathrm{~mm}$. 

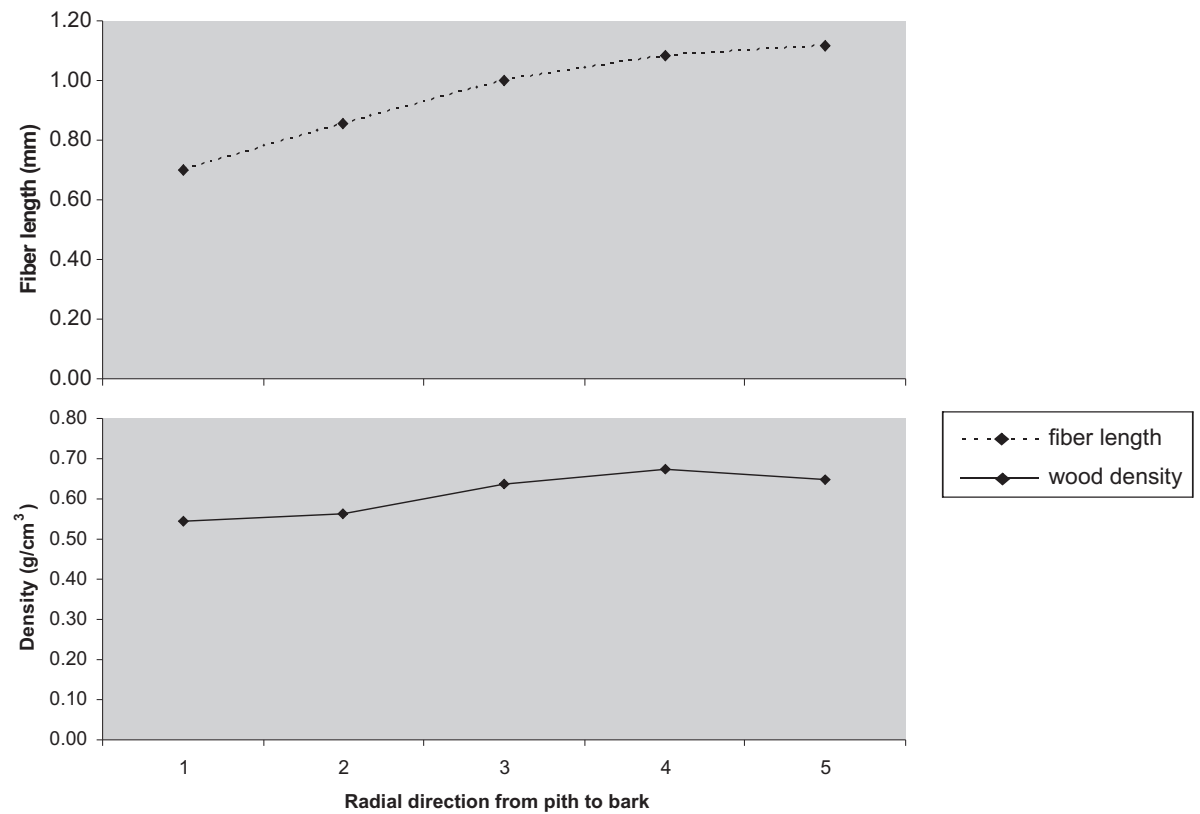

Figure 2. Variation in wood density (above) and fiber length (bottom) of E. pellita in radial position (from pith to bark) of Pleihari's SSO, South Kalimantan

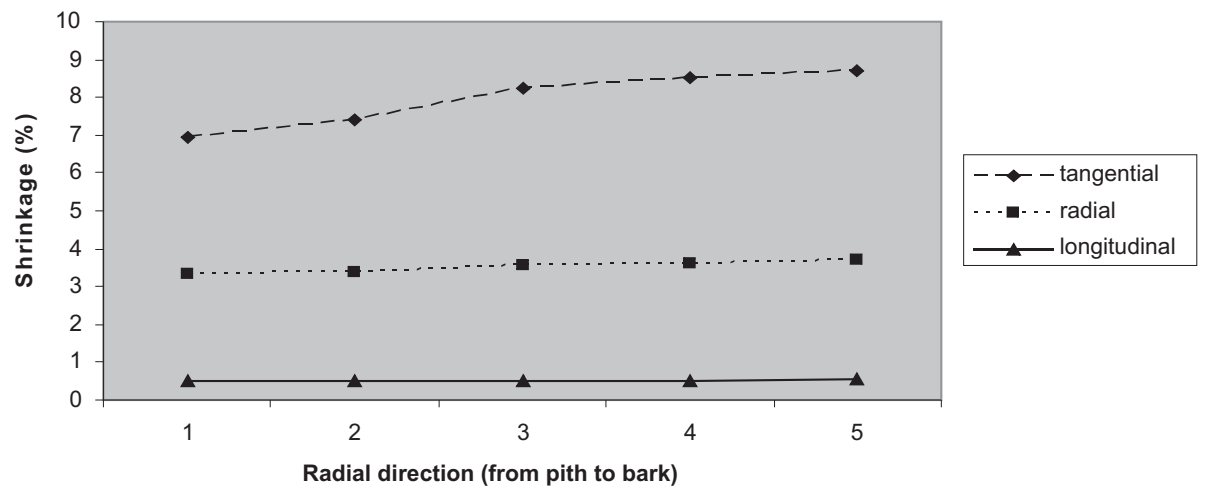

Figure 3. Variation in shrinkage of E. pellita in radial direction of Pleihari's SSO, South Kalimantan

Radial shrinkage ranged from $3.24 \%$ (family no 62 ) to $3.88 \%$ (family no 2 ) with average of $3.48 \%$. Longitudinal shrinkage also varied from $0.44 \%$ (family no 48 ) to $0.56 \%$ (family no 2 ), with an average of $0.51 \%$. Figure 4 showed clearly that radial and longitudinal shrinkages were significantly different among families of E. pellita, while tangential shrinkage on the contrary was not different. 


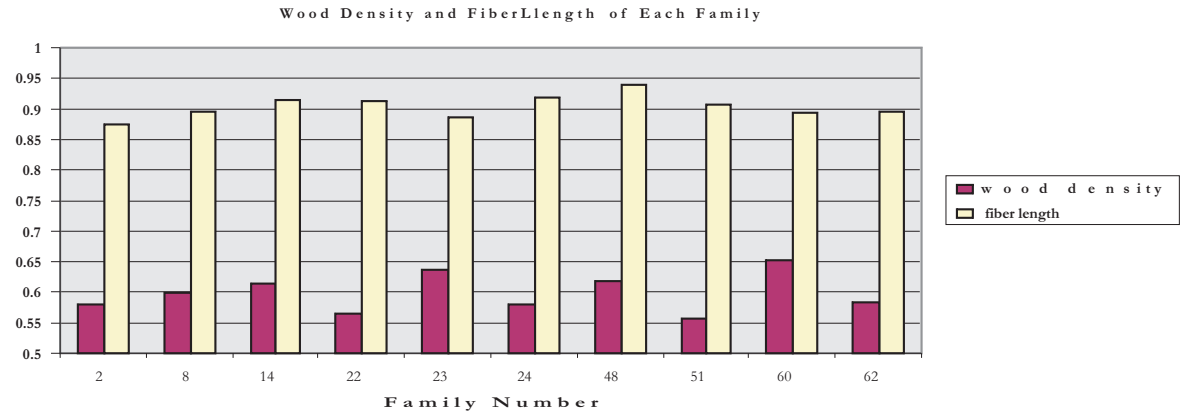

Wood Density and Longitudinal Shrinkages of Each Family

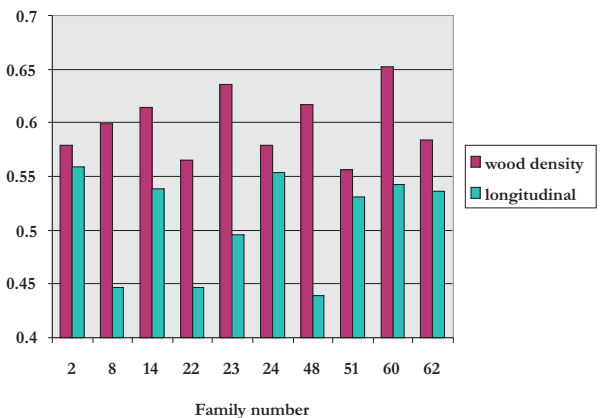

Wood Density and Radial Shrinkages of Each Family

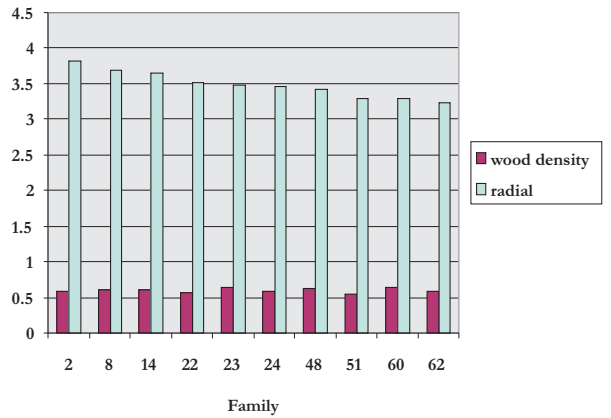

Figure 4. Variation in wood physical properties among family of E. pellita in Pleihari's SSO, South Kalimantan

Estimation of family heritability as described in Table 3 showed that only wood density had a high family heritability (0.709). For the other genetic parameter, even though their family heritability showed highly significant difference, unfortunately it could not be calculated due to the negative value of their family variance component value.

Based on the statistical analysis shown in Table 2, there was a highly significant interaction between family and axial positions in the stem (bottom, middle and top) for radial and longitudinal shrinkages. In addition, the significant interaction also occurred between family and radial position in the stem from pith to bark for fiber length $(\mathrm{P}=99 \%)$ and for wood density ( $\mathrm{P}=95 \%)$. 
Table 3. The Estimated mean value of the genetic parameter, probability, variance component (family), means square of variance component (family), coefficient of component variance (family) and family heritability

\begin{tabular}{|c|c|c|c|c|c|c|}
\hline Genetic Parameters & Mean & $\begin{array}{c}\text { Probability } \\
\operatorname{Pr}>\text { F }\end{array}$ & $\begin{array}{c}\text { Variance } \\
\text { (F) }\end{array}$ & $\mathrm{MS}_{(\mathrm{F})}$ & $\begin{array}{l}\text { Coefficient } \\
\text { Var iation }\end{array}$ & $\begin{array}{l}\text { Heritability } \\
\qquad\left(\mathrm{h}^{2}\right)\end{array}$ \\
\hline Wood density & $0.60 \mathrm{gr} / \mathrm{cm}^{3}$ & $0.0001^{* *}$ & 0.00066657 & 0.03148815 & 33.476 & 0.70865063 \\
\hline Fiber length & $0.90 \mathrm{~mm}$ & $0.0001^{* *}$ & -0.00004647 & 0.01220673 & 34.080 & 0 \\
\hline Tangential shrinkage & $7.76 \%$ & $0.0001^{* *}$ & -0.01725562 & 1.09180094 & 34.883 & 0 \\
\hline Radial shrinkage & $3.48 \%$ & $0.0087^{* *}$ & -0.00340275 & 1.24716467 & 34.883 & 0 \\
\hline Longitudinal shrinkage & $0.51 \%$ & $0.0043^{* *}$ & -0.00336298 & 0.08180951 & 34.883 & 0 \\
\hline
\end{tabular}

Note: $\left.{ }^{* *}\right)$ highly significant difference $(99 \%)$

Although wood density and fiber length reveal opposite (reverse) trends in axial direction as described in Figure 1, in all there was significant correlation ( $\mathrm{r}$ ) between wood density and fiber length $(\mathrm{r}=0.534)$ as seen in Figure 5. Therefore, it implies that either wood density or fiber length could be used as a genetic parameter in evaluating performance of SSO for tree selection

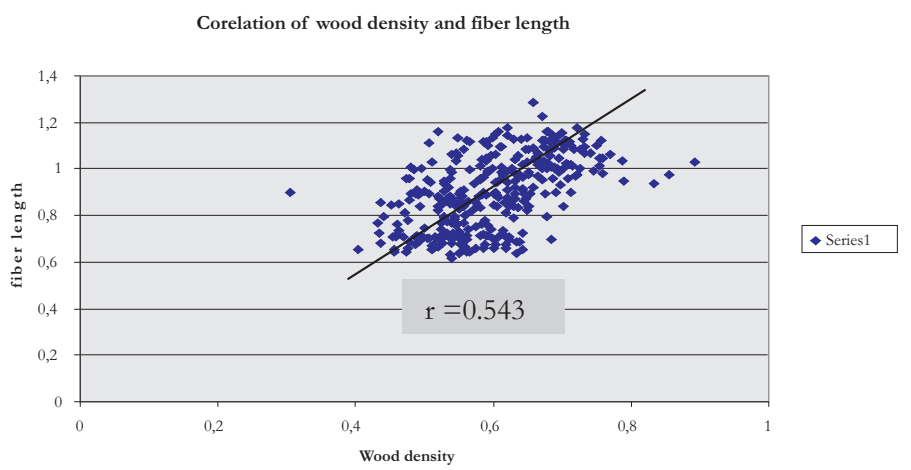

Figure 5. Relationship between wood density and fiber length

As compared to the work done by Susilawati and Fujisawa, (2002), who reported average of wood density and fiber length of $0.68 \mathrm{~g} / \mathrm{cm}^{3}$ and $0.98 \mathrm{~mm}$ respectively, it seems that the results of this study showed a lower average wood density and fiber length i.e. 0.60 $\mathrm{g} / \mathrm{cm}^{3}$ and $0.90 \mathrm{~mm}$ respectively. These discrepancies could happen due to different sampling method implemented in the collection of research (wood) sample. Susilawati and Fujisawa (2002) collected as many as 191 selected tree samples comprising 24 family using increment borer. Meanwhile, this study only used 10 families of E. pellita, and moreover the sampled trees (which allowed) to be felled were in the worst condition. As a result, it was reflected to the lower average value of wood density and fiber length. 


\section{CONCLUSION}

There were highly significant differences in wood density and fiber length of Eucalyptuspellita in Pleihari's SSO and in axial (from bottom, middle and top part) as well as in radial direction (from pith to bark). Meanwhile, tangential and radial shrinkages showed highly significant differences only for radial (section) position. Highly significant differences were also found among the families of the trees for wood density, fiber length and radial shrinkage, while its longitudinal shrinkage only showed significant differences. Wood density revealed high family heritability and it could be used as selection parameter in tree improvement program for E. pellita.

\section{ACKNOWLEDGEMENT}

The authors would like to express their sincere appreciation and deep gratitude for providing funding and services in supporting this research, particularly to Director of Center for Plantation Forest Research and Development (CPFRD), Yogyakarta and the Dean and Staff of Faculty of Forestry, Gajah Mada University. Further appreciation and gratitude were also extended to PT Inhutani III South Kalimantan for kindly assisting in sample collection in the field, especially to Mr. Soleh. At last but not least, wish thanks were also forwarded to authors' colleagues in the Laboratory of Wood Properties at CPFRD, and the Laboratory of Forest Product Technology, Gadjah Mada University for their meticulous efforts in sample collection and measurement, particularly Setyobudi, Mashudi and Joko Sulistyo.

\section{REFERENCES}

Anonim. 1957. Method of testing small clear specimens of timber. British Standard-373. London.

Harwood, C., D Alloysius, P.C Pomroy, K.W Robson and M.W. Haines. 1997. Early growth and survival of E. pellita provenance in range of tropical environment compared with E. grandis, E. urophylla and A. mangium. New Forest 14 :203-219. Netherlands.

Leksono, B. and S. Kurinobu. 2002. Genotype by environment interaction estimated in seedling seed orchard of Eucalyptus pellita established in South Kalimantan and South Sumatera, Indonesia. Proceeding of International Seminar "Advances in Genetic Improvement Tree Species'. CFBTI-JICA. Yogyakarta 1-3 October 2002. Indonesia.

Leksono, B. and T. Setyaji. 2004. The variation of height and diameter growth on progeny test of Eucalyptuspellita by single population system. Jurnal Penelitian Hutan Tanaman. Vol 1. No.2. Agustus 2004. Pusat Penelitian dan Pengembangan Bioteknologi dan Pemuliaan Hutan Tanaman. Yogyakarta. 
Susilawati, S. and Y. Fujisawa. 2002. Family variation on wood density and fiber length of Eucalyptus pellita in Seedling Seed Orchard, Pleihari, South Kalimantan. Proceeding of International Seminar "Advances in Genetic Improvement Tree Species'. CFBTIJICA. Yogyakarta 1-3 October 2002. Indonesia.

Wright, J.W. 1976. Introduction to Forest Genetics. Academic Press, Inch. San Diego. California.

Zobel, J. and J. Talbert. 1984. Applied Forest Tree Improvement. John Wiley \& Sons, Inch. Illinois. 
Appendix 1. Result of Duncan's Multiple Range Test (DMRT) of physical properties of Eucalyptuspellita from SSO in Pleihari, South Kalimantan

1. DMRT on Wood density of Eucalyptuspellita in family

\begin{tabular}{|c|c|c|c|}
\hline Duncan class & Mean & N & Family Number $\left.{ }^{*}\right)$ \\
\hline A & 0.65193 & 35 & 60 \\
\hline AB & 0.63165 & 28 & 48 \\
\hline B & 0.61719 & 39 & 14 \\
\hline BC & 0.61417 & 34 & 8 \\
\hline BCD & 0.59928 & 33 & 62 \\
\hline CDE & 0.58383 & 31 & 3 \\
\hline DE & 0.57953 & 34 & 22 \\
\hline DE & 0.57905 & 33 & 51 \\
\hline E & 0.56496 & 33 & 35 \\
\hline
\end{tabular}

*) Total number of family was 10 , each code-named as family number $(60,23, \ldots, 51)$; $\mathrm{N}=$ total number of sample in each family

2. DMRT on wood density of Eucalyptuspellita in axial position (bottom, middle and top)

\begin{tabular}{|c|c|c|c|}
\hline Duncan class & Mean & N & Part *) \\
\hline A & 0.612159 & 98 & Top \\
\hline A & 0.610525 & 111 & Middle \\
\hline B & 0.575383 & 126 & Bottom \\
\hline
\end{tabular}

*) Total number of axial position was 3, each part code named as top, middle and bottom stem; $\mathrm{N}=$ total number of sample in each part

3. DMRT on wood density of Eucalyptuspellita in radial direction from pith to bark

\begin{tabular}{|c|c|c|c|}
\hline Duncan class & Mean & N & Section *) \\
\hline A & 0.66707 & 52 & 3 \\
\hline AB & 0.64222 & 15 & 2 \\
\hline B & 0.63729 & 89 & 1 \\
\hline C & 0.56197 & 90 & E \\
\hline C & 0.54653 & 89 & 4 \\
\hline
\end{tabular}

*) From pith to bark corresponds to section number E, 1, 2,3 and 4. $\mathrm{N}=$ Number of sample in each section 
4. DMRT on fiber length of Eucalyptus pellita in family

\begin{tabular}{|c|c|c|c|}
\hline Duncan class & Mean & Family Number \\
\hline A & 0.93941 & 39 & 48 \\
\hline AB & 0.91793 & 35 & 24 \\
\hline B & 0.91464 & 33 & 14 \\
\hline B & 0.91236 & 35 & 51 \\
\hline BC & 0.90723 & 35 & 62 \\
\hline BCD & 0.89532 & 32 & 3 \\
\hline BCD & 0.89462 & 33 & 60 \\
\hline BCD & 0.89323 & 37 & 23 \\
\hline D & 0.88674 & 30 & 2 \\
\hline
\end{tabular}

*) Total number of family was 10 , each code-named as family number $(60,23, \ldots, 51)$; $\mathrm{N}=$ total number of sample in each family

5. DMRT on fiber length of Eucalyptus pellita in axial position (bottom, middle and top)

\begin{tabular}{|c|c|c|c|}
\hline Duncan class & Mean & N & Part \\
\hline A & 0.920341 & 126 & Bottom \\
\hline B & 0.906111 & 114 & Middle \\
\hline C & 0.882774 & 101 & Top \\
\hline
\end{tabular}

*) Total number of axial position was 3, each part code named as top, middle and bottom stem ; $\mathrm{N}=$ total number of sample in each part

6. DMRT on fiber length of Eucalyptus pellita in radial position from pith to bark

\begin{tabular}{|c|c|c|c|}
\hline Duncan cla ss & Mean & N & Section \\
\hline A & 1.110520 & 15 & 3 \\
\hline B & 1.087607 & 57 & 2 \\
\hline C & 1.002362 & 90 & 1 \\
\hline D & 0.857596 & 90 & E \\
\hline E & 0.700811 & 89 & 3 \\
\hline
\end{tabular}

*) From pith to bark corresponds to section number E, 1, 2,3 and 4. $\mathrm{N}=$ Number of sample in each section

7. DMRT on tangential shrinkage of Eucalyptus pellita in radial position from pith to bark.

\begin{tabular}{|c|c|c|c|}
\hline Duncan class & Mean & N & Section \\
\hline A & 8.7177 & 21 & 4 \\
\hline AB & 8.4899 & 58 & 2 \\
\hline B & 8.2425 & 90 & 1 \\
\hline C & 7.3856 & 90 & E \\
\hline D & 6.9482 & 90 & 3 \\
\hline
\end{tabular}

*) From pith to bark corresponds to section number E, 1, 2,3 and 4. $N=$ Number of sample in each section 
8. DMRT on radial shrinkage of Eucalyptus pellita in family

\begin{tabular}{|c|c|c|c|}
\hline Duncan class & Mean & Family Number \\
\hline$A$ & 3.8195 & 34 & 2 \\
\hline$A B$ & 3.6816 & 35 & 24 \\
\hline$A B C$ & 3.6418 & 35 & 51 \\
\hline ABCD & 3.5139 & 34 & 23 \\
\hline ABCD & 3.4869 & 30 & 48 \\
\hline BCD & 3.4508 & 39 & 60 \\
\hline BCD & 3.4291 & 37 & 8 \\
\hline CD & 3.2819 & 35 & 3 \\
\hline CD & 3.2818 & 33 & 37 \\
\hline D & 3.2403 & 37 & 8 \\
\hline
\end{tabular}

*) Total number of family was 10 , each code-named as family number $(60,23, \ldots, 51)$; $\mathrm{N}=$ total number of sample in each family

9. DMRT on radial shrinkage of Eucalyptus pellita in radial position from pith to bark

\begin{tabular}{|c|c|c|c|}
\hline Duncan class & Mean & N & Section \\
\hline$A$ & 3.7413 & 21 & 4 \\
\hline$A B$ & 3.6468 & 58 & 3 \\
\hline$A B C$ & 3.5521 & 90 & 1 \\
\hline BC & 3.3690 & 90 & E \\
\hline C & 3.3534 & 90 & 2 \\
\hline
\end{tabular}

*) From pith to bark corresponds to section number E, 1,2,3 and 4. $\mathrm{N}=$ Number of sample in each section

10. DMRT on longitudinal shrinkage of Eucalyptus pellita in family

\begin{tabular}{|c|c|c|c|}
\hline Duncan class & Mean & N & Family Number \\
\hline$A$ & 0.55883 & 34 & 2 \\
\hline$A B$ & 0.55321 & 35 & 60 \\
\hline$A B C$ & 0.54188 & 37 & 8 \\
\hline$A B C$ & 0.53835 & 33 & 62 \\
\hline$A B C$ & 0.53570 & 34 & 51 \\
\hline$A B C$ & 0.53053 & 35 & 3 \\
\hline$A B C$ & 0.49574 & 30 & 14 \\
\hline BC & 0.44676 & 37 & 48 \\
\hline BC & 0.44642 & 35 & 39 \\
\hline
\end{tabular}

*) Total number of family was 10 , each code-named as family number $(60,23, \ldots, 51) ; \mathrm{N}=$ total number of sample in each family 
Appendix 2. Wood density and fiber length of 116 months E. pellita in axial direction from Seedling Seed Orchard, Pleihari, South Kalimantan

\begin{tabular}{|c|c|c|c|c|c|c|c|c|c|}
\hline \multirow[t]{2}{*}{ No } & \multirow[t]{2}{*}{ Row } & \multirow[t]{2}{*}{ Column } & \multirow[t]{2}{*}{ Family } & \multicolumn{3}{|c|}{ Density $\left(\mathrm{g} / \mathrm{cm}^{3}\right)$} & \multicolumn{3}{|c|}{ Fiber Length (mm) } \\
\hline & & & & Bottom & Medium & Top & Bottom & Medium & Top \\
\hline 1 & 25 & 14 & 2 & 0.52 & 0.53 & 0.54 & 0.903 & 0.833 & 0.856 \\
\hline 4 & 38 & 8 & 2 & 0.56 & 0.63 & 0.63 & 0.863 & 0.914 & 0.846 \\
\hline 7 & 49 & 15 & 2 & 0.53 & 0.60 & 0.57 & 0.919 & 0.867 & 0.834 \\
\hline 10 & 7 & 24 & 3 & 0.55 & 0.57 & 0.61 & 0.845 & 0.843 & 0.877 \\
\hline 13 & 10 & 11 & 3 & 0.58 & 0.62 & 0.61 & 0.912 & 0.898 & 0.928 \\
\hline 16 & 50 & 27 & 3 & 0.53 & 0.54 & 0.61 & 0.922 & 0.901 & 0.897 \\
\hline 19 & 6 & 22 & 8 & 0.58 & 0.59 & 0.59 & 0.959 & 0.906 & 0.887 \\
\hline 22 & 15 & 27 & 8 & 0.55 & 0.63 & 0.63 & 0.879 & 0.880 & 0.904 \\
\hline 25 & 34 & 29 & 8 & 0.59 & 0.62 & 0.63 & 0.950 & 0.921 & 0.895 \\
\hline 28 & 14 & 17 & 14 & 0.61 & 0.64 & 0.73 & 0.910 & 0.909 & 0.873 \\
\hline 31 & 22 & 23 & 14 & 0.61 & 0.58 & 0.62 & 0.958 & 0.928 & 0.870 \\
\hline 34 & 33 & 19 & 14 & 0.52 & 0.61 & 0.59 & 0.862 & 0.947 & 0.915 \\
\hline 37 & 11 & 24 & 23 & 0.63 & 0.64 & 0.67 & 0.900 & 0.865 & 0.901 \\
\hline 40 & 28 & 20 & 23 & 0.62 & 0.58 & 0.60 & 0.918 & 0.853 & 0.866 \\
\hline 43 & 49 & 24 & 23 & 0.64 & 0.66 & 0.66 & 0.878 & 0.908 & 0.870 \\
\hline 46 & 6 & 30 & 24 & 0.63 & 0.65 & 0.61 & 0.901 & 0.941 & 0.887 \\
\hline 49 & 37 & 14 & 24 & 0.56 & 0.63 & 0.66 & 0.980 & 0.941 & 0.881 \\
\hline 52 & 47 & 20 & 24 & 0.50 & 0.53 & 0.52 & 0.939 & 0.891 & 0.879 \\
\hline 55 & 6 & 16 & 48 & 0.61 & 0.67 & 0.62 & 0.973 & 0.936 & 0.852 \\
\hline 58 & 12 & 23 & 48 & 0.55 & 0.63 & 0.63 & 0.973 & 0.916 & 0.837 \\
\hline 61 & 23 & 26 & 48 & 0.58 & 0.64 & 0.64 & 0.957 & 0.971 & 0.964 \\
\hline 64 & 16 & 17 & 51 & 0.60 & 0.65 & 0.59 & 0.914 & 0.920 & 0.857 \\
\hline 67 & 32 & 23 & 51 & 0.52 & 0.57 & 0.57 & 0.943 & 0.907 & 0.838 \\
\hline 70 & 43 & 19 & 51 & 0.51 & 0.45 & 0.57 & 0.945 & 0.919 & 0.883 \\
\hline 73 & 21 & 26 & 60 & 0.65 & 0.72 & 0.65 & 0.871 & 0.882 & 0.831 \\
\hline 76 & 41 & 17 & 60 & 0.60 & 0.72 & 0.64 & 0.911 & 0.863 & 0.875 \\
\hline 79 & 46 & 30 & 60 & 0.62 & 0.66 & 0.61 & 0.907 & 0.930 & 0.954 \\
\hline 82 & 8 & 28 & 62 & 0.57 & 0.60 & 0.61 & 0.915 & 0.892 & 0.831 \\
\hline 85 & 14 & 11 & 62 & 0.53 & 0.56 & 0.60 & 0.842 & 0.920 & 0.928 \\
\hline \multirow[t]{2}{*}{88} & 34 & 16 & 62 & 0.59 & 0.62 & 0.59 & 0.933 & 0.866 & 0.886 \\
\hline & \multicolumn{3}{|l|}{ Average } & 0.57 & 0.61 & 0.61 & 0.916 & 0.902 & 0.880 \\
\hline
\end{tabular}


Appendix 3. Wood density and fiber length of 116 months E. pellita in radial direction from Seedling Seed Orchard, Pleihari, South Kalimantan

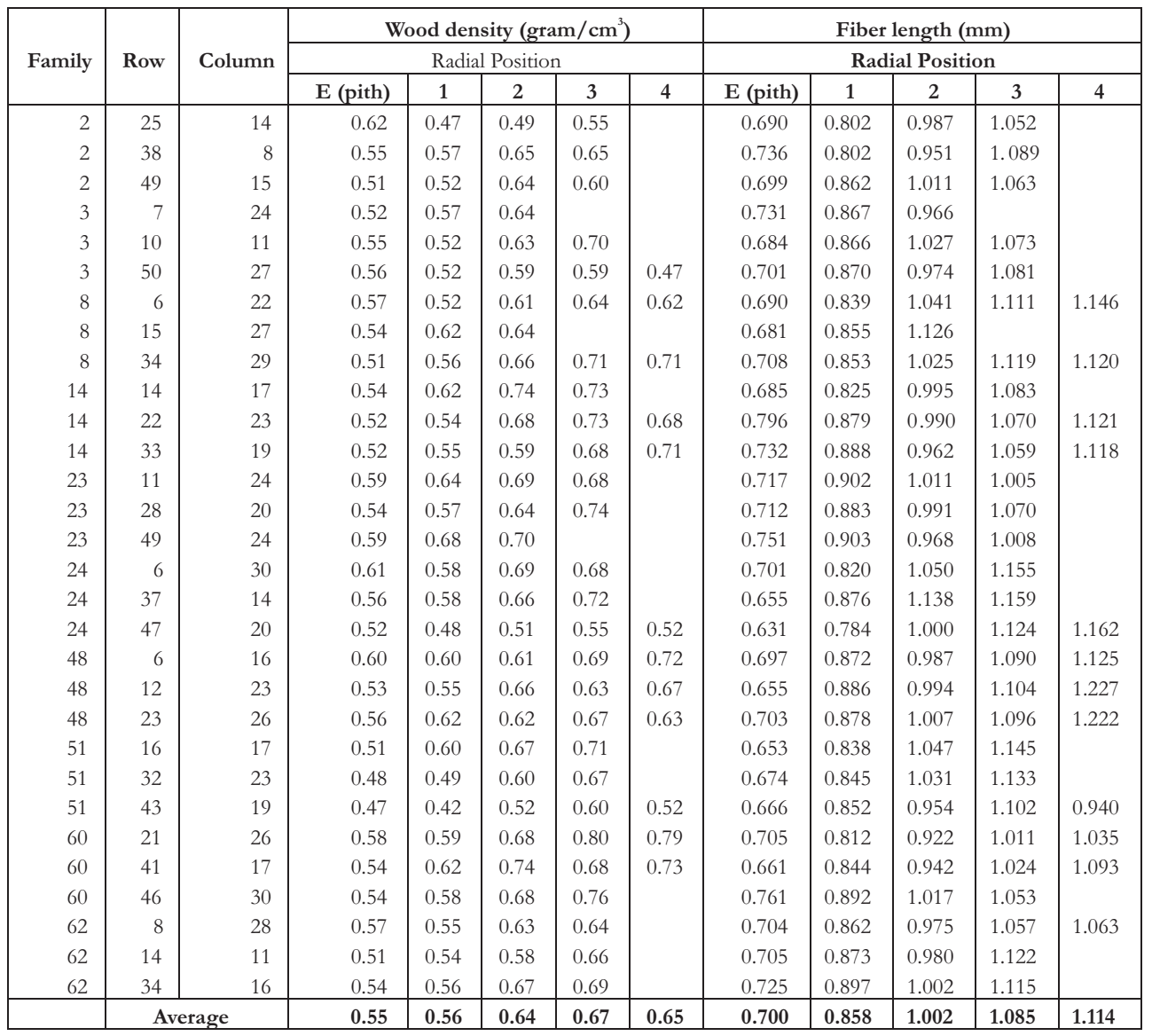


Appendix 4. Tangential, radial and longitudinal shrinkage of 116 months E. pellita in radial direction from Seedling Seed Orchard, Pleihari, South Kalimantan

\begin{tabular}{|c|c|c|c|c|c|c|c|c|c|c|c|c|c|c|c|c|c|}
\hline \multirow{3}{*}{ Family } & \multirow{3}{*}{ Row } & \multirow{3}{*}{ Column } & \multicolumn{5}{|c|}{ Tangential shrinkage $(\%)$} & \multicolumn{5}{|c|}{ Radial shrinkage (\%) } & \multicolumn{5}{|c|}{ Longitudinal shrinkage (\%) } \\
\hline & & & \multicolumn{5}{|c|}{ Radial Position } & \multicolumn{5}{|c|}{ Radial Position } & \multicolumn{5}{|c|}{ Radial Position } \\
\hline & & & $\begin{array}{c}\mathbf{E} \\
\text { (pith) }\end{array}$ & 1 & 2 & 3 & 4 & $\begin{array}{c}\mathbf{E} \\
\text { (pith) }\end{array}$ & 1 & 2 & 3 & 4 & $\begin{array}{c}\mathbf{E} \\
\text { (pith) }\end{array}$ & 1 & 2 & 3 & 4 \\
\hline 2 & 25 & 14 & 7.68 & 6.78 & 7.83 & 8.32 & & 4.18 & 3.67 & 3.89 & 4.28 & & 0.76 & 0.51 & 0.56 & 0.69 & \\
\hline 2 & 38 & 8 & 6.34 & 6.89 & 7.48 & 7.97 & & 3.74 & 3.23 & 3.31 & 3.84 & & 0.75 & 0.57 & 0.39 & 0.41 & \\
\hline 2 & 49 & 15 & 7.90 & 6.89 & 7.98 & 8.85 & & 3.47 & 3.94 & 4.20 & 4.24 & & 0.64 & 0.45 & 0.48 & 0.41 & \\
\hline 3 & 7 & 24 & 6.95 & 8.62 & 8.41 & 9.73 & & 3.13 & 2.72 & 2.93 & 3.21 & & 0.50 & 0.63 & 0.72 & 0.66 & \\
\hline 3 & 10 & 11 & 6.59 & 7.47 & 7.98 & 7.84 & 8.56 & 3.58 & 3.11 & 3.31 & 3.55 & 3.89 & 0.28 & 0.34 & 0.27 & 0.27 & 0.44 \\
\hline 3 & 50 & 27 & 7.89 & 7.60 & 7.54 & 8.07 & 9.16 & 2.82 & 2.99 & 3.56 & 3.82 & 2.31 & 0.46 & 0.39 & 0.56 & 0.27 & 0.91 \\
\hline 8 & 6 & 22 & 7.28 & 7.10 & 7.64 & 8.80 & 8.50 & 2.56 & 3.50 & 3.46 & 3.46 & 2.55 & 0.70 & 0.52 & 0.57 & 0.46 & 0.56 \\
\hline 8 & 15 & 27 & 5.98 & 7.44 & 7.87 & & & 3.25 & 3.56 & 3.42 & & & 0.55 & 0.49 & 0.41 & & \\
\hline 8 & 34 & 29 & 7.29 & 7.62 & 8.49 & 8.98 & 8.96 & 3.09 & 3.21 & 3.44 & 3.33 & 3.71 & 0.72 & 0.47 & 0.47 & 0.56 & 0.43 \\
\hline 14 & 14 & 17 & 5.98 & 6.83 & 8.46 & 9.02 & & 3.15 & 2.93 & 3.12 & 3.15 & & 0.67 & 0.29 & 0.46 & 0.19 & \\
\hline 14 & 22 & 23 & 6.61 & 7.30 & 8.77 & 8.59 & 7.00 & 3.28 & 3.30 & 3.48 & 2.47 & 4.69 & 0.55 & 0.47 & 0.28 & 0.34 & 0.15 \\
\hline 14 & 33 & 19 & 6.59 & 7.58 & 7.49 & 8.69 & 8.89 & 3.42 & 3.44 & 3.53 & 3.77 & 2.38 & 0.50 & 0.45 & 0.64 & 0.55 & 0.34 \\
\hline 23 & 11 & 24 & 6.90 & 7.52 & 7.89 & 5.61 & & 3.07 & 3.20 & 4.05 & 3.35 & & 0.48 & 0.40 & 0.52 & 0.54 & \\
\hline 23 & 28 & 20 & 7.34 & 7.60 & 8.58 & 8.85 & & 3.91 & 3.41 & 3.06 & 3.23 & & 0.40 & 0.38 & 0.48 & 0.34 & \\
\hline 23 & 49 & 24 & 7.78 & 7.10 & 8.61 & & & 3.54 & 3.64 & 3.73 & & & 0.76 & 0.59 & 0.55 & & \\
\hline 24 & 6 & 30 & 6.60 & 7.54 & 8.75 & 7.56 & & 3.56 & 3.79 & 3.33 & 3.55 & & 0.45 & 0.39 & 0.39 & 0.90 & \\
\hline 24 & 37 & 14 & 6.64 & 8.54 & 8.92 & 8.75 & 9.67 & 3.27 & 3.73 & 3.48 & 4.54 & 4.51 & 0.41 & 0.52 & 0.62 & 0.58 & 0.57 \\
\hline 24 & 47 & 20 & 7.90 & 7.52 & 8.19 & 8.22 & 8.22 & 2.84 & 3.37 & 4.12 & 4.56 & 4.56 & 0.69 & 0.56 & 0.66 & 0.66 & 0.39 \\
\hline 48 & 6 & 16 & 7.18 & 8.51 & 8.68 & 9.20 & 9.15 & 2.70 & 3.43 & 3.36 & 2.86 & 3.22 & 0.50 & 0.46 & 0.46 & 0.46 & 0.47 \\
\hline 48 & 12 & 23 & 6.36 & 7.40 & 8.31 & 8.84 & 9.38 & 3.68 & 3.62 & 4.15 & 3.95 & 3.96 & 0.26 & 0.48 & 0.30 & 0.42 & 0.63 \\
\hline 48 & 23 & 26 & 5.98 & 7.37 & 8.83 & 8.54 & 9.96 & 3.36 & 3.12 & 3.53 & 3.51 & 4.33 & 0.29 & 0.30 & 0.62 & 0.56 & 0.64 \\
\hline 51 & 16 & 17 & 6.75 & 7.01 & 8.96 & 9.27 & 9.19 & 3.47 & 3.09 & 3.59 & 3.52 & 4.59 & 0.64 & 0.63 & 0.72 & 0.79 & 0.95 \\
\hline 51 & 32 & 23 & 7.64 & 7.22 & 7.48 & 8.45 & & 3.59 & 2.99 & 3.89 & 4.03 & & 0.39 & 0.54 & 0.45 & 0.28 & \\
\hline 51 & 43 & 19 & 6.27 & 6.53 & 7.90 & 8.24 & 8.64 & 3.75 & 3.63 & 3.83 & 3.85 & 4.06 & 0.27 & 0.56 & 0.45 & 0.50 & 0.66 \\
\hline 60 & 21 & 26 & 6.21 & 7.54 & 8.10 & 8.63 & 8.88 & 2.81 & 3.56 & 3.79 & 3.85 & 4.16 & 0.52 & 0.55 & 0.53 & 0.32 & 0.54 \\
\hline 60 & 41 & 17 & 7.32 & 6.79 & 8.60 & 8.85 & 9.31 & 3.16 & 3.56 & 3.38 & 3.49 & 4.13 & 0.56 & 0.64 & 0.59 & 0.29 & 0.67 \\
\hline 60 & 46 & 30 & 6.79 & 7.32 & 8.50 & 8.86 & & 2.81 & 3.21 & 3.27 & 3.65 & & 0.55 & 0.71 & 0.70 & 0.37 & \\
\hline 62 & 8 & 28 & 8.57 & 7.46 & 8.02 & 7.80 & 8.25 & 3.61 & 3.30 & 3.73 & 3.37 & 3.65 & 0.50 & 0.47 & 0.57 & 0.41 & 0.31 \\
\hline 62 & 14 & 11 & 6.95 & 8.21 & 8.68 & 7.94 & 6.10 & 4.33 & 3.65 & 3.57 & 4.16 & 2.55 & 0.42 & 0.57 & 0.59 & 0.48 & 0.60 \\
\hline 62 & 34 & 16 & 6.21 & 6.27 & 8.34 & 9.43 & & 3.47 & 3.18 & 3.06 & 2.50 & & 0.70 & 0.44 & 0.61 & 0.93 & \\
\hline Average & & & 6.95 & 7.39 & 8.24 & 8.50 & 8.70 & 3.35 & 3.37 & 3.55 & 3.61 & 3.72 & 0.53 & 0.49 & 0.52 & 0.49 & 0.54 \\
\hline
\end{tabular}

